\title{
No descanso eterno entre lápides e epitáfios: São Miguel Arcanjo e Consolação
}

\author{
Maria Célia LIMA-HERNANDES ${ }^{1}$ \\ Roberval TEIXEIRA e SILVA ${ }^{2}$
}

\section{Apresentação}

A cessação da vida é temida por todos, mesmo pelos cristãos que - segundo sua doutrina - irão ao encontro do Pai Eterno, mas eles não são os únicos que a temem. Entre os maometanos, por exemplo, é comum que se use uma cauda nas roupas para que seus rastros não sejam deixados na areia do deserto a fim de que a morte não os encontre (cf. Silva; Carvalho; Toledo, 1968, p. 1158).

Duas correntes antropológicas, o Difusionismo e o Migracionismo, amparam os interesses que revelamos nesta pesquisa.

\footnotetext{
Universidade de São Paulo (USP), Conselho Nacional de Desenvolvimento Científico e Tecnológico (CNPq), Fundação de Amparo à Pesquisa do Estado de São Paulo (Fapesp); mceliah@usp.br

2 Universidade de Macau; roberval.ts@gmail.com
} 
Ambas as correntes consideram que "grupos diferentes apresentam características culturais semelhantes a partir da transferência entre grupos" (Ribeiro, 2007, p. 50). A última corrente, como o próprio nome antecipa, foca a mobilidade geográfica de sujeitos, os quais passam a integrar um outro espaço em cujas rotinas e práticas sociais se inspiram, integrando-as à sua rotina. O mesmo se costuma afirmar da comunidade local, que pode absorver práticas dessa comunidade imigrante. O Difusionismo, por sua vez, prioriza a concepção de "contato cultural e imitação de um grupo por outro" (RibeIRo, 2007, p. 50).

Quem conhece Macau ou São Paulo e a dinâmica social que nessas cidades se desenha, ao tentar classificar a corrente que melhor se adequa ao caso, ficaria sem saber como tomar essa decisão, pois, a depender das experiências vivenciadas em tais espaços multiculturais, uma ou outra poderia ser atestada. Conhecer Macau e também São Paulo pressupõe viver esferas tão diversas quanto as camadas sociais (e migratórias) historicamente incorporadas (ou mesmo politicamente ignoradas) à sua população.

Em seu estudo, Ribeiro (2007) já evidenciara a importância de voltar a atenção para as práticas mortuárias como locus de reconhecimento do grau de interpenetração cultural. Considerando Macau como espaço de observação, logo nos sentimos obrigados a concordar com as descobertas de vários antropólogos que se detiveram no estudo de rituais dessa natureza: não se trata de uma mudança de uma cultura pelo contato já que "as mudanças tendem a ocorrer em ambos os grupos, o que alteraria ambas as culturas” (RiBeIro, 2007, p. 53). Também obras diversas já exibiram o choque cultural que têm lugar nessas cenas rituais. ${ }^{3}$

3 Vomero (2002) lembra o episódio "Povoado do Moinho", do filme Sonhos (1992), 
Como podemos notar e como bem afirmou Ruffié (1988), esses rituais ocupam um lugar tão especial na vida dos humanos ${ }^{4}$ que podem ser equiparados ao da sexualidade. Assim é que, para se falar de uma cultura, por assim dizer, será fundamental a observação do modo como os rituais de morte se consolidam nos diferentes grupos humanos.

Segundo Bertolli Filho e Meihi (1983), é possível analisar a temática de dois modos: por reconhecimento direto e também indireto. No primeiro caso, o fenômeno da morte é observado em sua plenitude, sem restrições, o que faz com que o investigador a focalize como núcleo de análise, como ponto de partida e de chegada. Na segunda perspectiva, alcança-se a morte por meio de discursos evasivos, suficientemente agregados de simbologia e metaforismos. É um caminho contraditório, pois, ao mesmo tempo que se busca a compreensão da morte, é a vida que assume importância suprema. É um caminho em si paradoxal, mas o fenômeno é rico em complexidades e perspectivas.

Justamente por isso, antropólogos, quando em contato com outra cultura, descrevem ritos e hábitos ligados à morte. Benedict (s.d.), por exemplo, relata que os índios Pueblo do sudoeste se preocupam em auxiliar a pessoa enlutada a esquecer a dor vivenciada e o rito é levado a cabo para esse fim:

\footnotetext{
dirigido por Akira Kurosawa, em que um forasteiro presencia um ritual funerário de um vilarejo. Ali, pessoas locais celebravam a morte de uma mulher idosa, cantando e dançando, alegremente, pelas ruas. Sentimento similar, mas às avessas, vivenciou o monge budista, Sogyal Rinpoche, autor de O livro tibetano do viver e do morrer, em seu choque com relação à forma de morrer ocidental.

4 De acordo com Ruffié (1988, p. 223), "em todas as civilizações [...] a morte está presente no centro da vida social, e notadamente através dos ritos mortuários. A comunidade toma parte no desenlace: família, vizinhos, vilarejo ou tribo assistem o moribundo[...]". "Nada de parecido nas sociedades industriais, onde a morte é cuidadosamente ocultada [...]” (Ruffié, 1988, p. 225).
} 
Reúnem-se para alimentar o morto pela última vez e despedi-lo. Um dos padres asperge todos os presentes com a água sagrada do vaso e abre a porta da casa. $\mathrm{O}$ chefe dirige-se ao morto ordenando-lhe que venha comer. Ouvem os seus passos fora, e o seu tatear à porta. O morto entra e come. Então o chefe asperge o caminho que ele agora seguirá e os padres "expulsam-no da aldeia". Levam consigo as varas-de-orar pelo morto, os artigos de vestuário e os de seu uso pessoal, a escova de cabelo e o cesto com alimentos. Levam-no para fora da aldeia, partem a escova e o vaso, enterrando tudo. Voltam a casa a correr e sem olhar para trás, e trancam a porta contra o morto, gravando nela com uma faca de silex uma cruz para evitar que ele entre, o que corresponde ao formal rompimento com o morto. O chefe fala às pessoas dizendo-lhes que o esqueçam para sempre. Despedem-se as pessoas e terminou o luto. (p. 77)

Se seguirmos lendo esses materiais da antropologia social, logo verificaremos que, em grande medida, diferem-se as culturas $^{5}$ nessas situações de enfrentamento da morte.

A posição do corpo parece ser um dado relevante para estudos dessa natureza, como demonstraram Durkheim e Mauss, ${ }^{6}$ por exemplo, mas também o papel social do morto, numa abordagem da Antropologia Social Inglesa (Funcionalismo ${ }^{7}$ ) parece

5 Em Benedict, ainda lemos sobre as peculiaridades dos Zuñi e dos Dakotas.

6 Esses autores (apud Ribeiro, 2007) mostraram que, a depender do grupo totêmico, a cabeça do morto estaria voltada para um específico ponto cardeal.

7 Essa corrente de estudos parte de pressupostos de Malinovski (1922), que priorizou o entendimento das ações humanas e do sistema social a partir de necessidades biológicas, e de Radcliffe-Brown (1922), que priorizou o entendimento do papel social dos 
ter muito a dizer sobre o que identificamos em trabalho de campo. Nessa abordagem, constatamos a correlação entre o papel social do morto e os rituais de funeral, dentre os quais a escolha do jazigo. Em São Paulo, na mesma medida e com a mesma intensidade, pode-se falar em geografia de rituais. A multiculturalidade paulistana provoca a reflexão sobre o poder e o local de ritual de 'despedida'.

Esse tema não é novo e não são ineditismos do século XX ou de sociedades multiculturais o tratamento e a diferenciação entre mortos. Desde a Idade Média, ter túmulo individual constitui-se uma deferência (RoDRIGUEs, 1999²), e também o lugar geográfico do túmulo sempre foi uma diferença básica entre alguns. Lidar, contudo, com esse tema à luz dos hábitos coloniais pode ser, de algum modo, uma perspectiva diferente e uma contribuição à reflexão sobre a construção cultural do espaço.

Os lugares que confrontamos aqui são complexamente diferentes, mas guardam um traço comum: a colonização portuguesa. Essa semelhança permite discutir aspectos culturais de Macau e de São Paulo, sob a ótica da geografia humana e, a cada recorte, uma Macau diferente se apresentará assim como uma São Paulo diferente se revelará. No entanto, se propiciarmos um mesmo recorte temático para essa aproximação, acreditamos que experiências interessantes poderão nos surpreender.

indivíduos (cf. Ribeiro, 2007).

8 "Os sepulcros privados começaram a existir primeiro dentro, depois nas adjacências das igrejas, e por fim em lugares especialmente destinados a finalidades cemiteriais. [...] Síntese desse processo: a multiplicação dos túmulos individuais de início contemplou, é óbvio, os poderosos, nobres e clérigos; em seguida, os burgueses; depois, os pequenos burgueses; finalmente, os proletários, operários e camponeses. Todos passaram lentamente a ter, não apenas a vontade, mas, ao menos em teoria, o direito a uma sepultura individual" (Rodrigues, 1999, p. 130). 
Neste capítulo, o recorte escolhido para essa dupla visitação será aquele desenhado pelos cemitérios e pela temática que os abarca melhor: a morte e seus rituais, pois, segundo Magalhães (1997, p. 147), resenhando Braet e Verbeke (1996), esse é um tema rico que permite desvendar a estrutura das mentalidades humanas ou, como queria Vovelle (1996), favorece tomar contato com o "termômetro" da sociedade, que assume um comportamento grupal frente à morte.

\section{Duas ex-colônias e suas heranças culturais}

Tanto o Brasil quanto Macau são ex-colônias portuguesas e guardam em sua sociedade traços da longa estada de portugueses e da miscigenação ocorrida. No Brasil, não se distinguem filhos de portugueses ou descendentes desses de modo marcado. Há uma distinção comum como em outra parte qualquer haveria. Invariavelmente, somente por autodenúncia é que se identifica esse sujeito, pois a miscigenação foi bastante intensa e extensa no território brasileiro.

Em Macau, dado ser um território fincado no Oriente, a diferença entre portugueses e o povo asiático, mais especificamente o chinês, é marcada. No entanto, há filhos dessa miscigenação que pouca diferença revelam pela aparência. As diferenças vão se somando, na verdade, pelos hábitos e costumes locais que são integrados de modo 'misturado' na rotina dos macaenses, filhos da terra.

As rotinas e os hábitos em contexto de féretro não são claros quanto às tradições portuguesas, razão pela qual se torna interessante conhecer como eram esses costumes na idade média em Portugal. 


\subsection{A morte e o tratamento a cadáveres na Idade Média portuguesa}

A idade do velho era principiada, na lógica da Idade Média, com os cinquenta anos ${ }^{9}$. Essa realidade permite entender que todas as ações derivadas de uma sociedade em ebulição fossem, à época, adiantadas em experienciamento ${ }^{10}$. A taxa de mortalidade era, nesse período, grande e as faixas etárias de morte, muito baixas também. Isso se devia ao "incremento das epidemias e uma menor resistência às infecções" (apud Marques, 1971, p. 219) no século XIV. Era comum que famílias perdessem filhos em idade tenra, o que elevava, sobremaneira, a mortalidade infantil. Esse evento tão frequente fez com que a Igreja assumisse um discurso sobre "o fim dos prazeres do mundo e sobre a necessidade de cada cristão meditar na passagem para a vida eterna. Daí um surto no fervor religioso e nas práticas devotas" (Marques, 1971, p. 210).

Já nessa época, os cadáveres recebiam tratamentos distintos a depender de sua categoria social. Se de família nobre, o embalsamento era feito com substâncias aromáticas, o corpo

9 Na edição de Leal Conselheiro, feita por J. Piel, em 1942 (apud MArQues, 1971, p. 209), o rei D. Duarte apresenta a distribuição de fases da vida: "e as idades são por muitas maneiras repartidas, mas uma que põem os letrados, que bem me parece, chama infância até 7 anos, puerícia até 14 , até 21 adolescência, mancebia até cinquenta, velhice até 70 , senyum até 80 , e dali até o fim da vida decrepitude."

10 D. Duarte afirma que a melhor idade para o casamento é aos 14 anos de vida. Raramente alguém ultrapassava os 70: "Dos reis de Portugal só os dois fundadores de dinastia - D. Afonso Henriques e D. João I - ultrapassaram os setenta anos. À 'velhice' apenas chegaram quatro - D. Sancho I, D. Afonso III, D. Dinis e D. Afonso IV. Os demais ficaram-se pela 'mancebia'. Com as rainhas e infantas sucedia coisa parecida" (Marques, 1971, p. 210). 
era trajado com vestimentas ricas e enfeitado com joias ${ }^{11}$. Não é preciso dizer que outras classes não recebiam esse cuidado. As classes populares adotavam um tratamento mais simples e não havia cuidados diferenciados com roupas ou tecidos.

Quanto ao local do enterro, a situação social também era critério decisivo. Eclesiásticos, senhores de grande importância social e os que em vida pagaram ou testamentaram essa forma eram sepultados dentro das igrejas. Outro caminho era o destinado aos mais simples. Invariavelmente, eram enterrados junto às igrejas em terrenos anexos denominados passais (MARQUes, 1971) ou em terrenos particulares. As valas comuns eram destinadas a servos, escravos, indigentes e menos favorecidos.

\subsection{Um panorama pré-colonial da morte no Brasil}

A colonização foi tão impactante no Brasil que os hábitos e costumes alteraram muito a padronização de usos, o que era bem diverso antes. Os rituais de morte, segundo Fontes (1976), de tribo para tribo, eram diferentes.

Na tribo Urubu-Kaapor, a morte equivale à passagem para o reino de Maíra. Já, entre os Bororo, a morte

\footnotetext{
11 "A rainha Santa Isabel, cujo corpo teve de ser conduzido de Estremoz para Coimbra, depois de amortalhada no hábito de clarissa, foi enrolada num lençol de linho fino. Sobre ele ainda se puseram uma colcha de pano mais espesso, um envólucro de linho cru, muito grosseiro, cosido à agulha, e finalmente uma outra colcha de algodão branco e grosso. Foi depois metido o cadáver num ataúde rectangular de madeira, sobre o qual se pregou para maior resguardo um couro de boi com o pelo voltado para fora, revestido tudo de um pano de púrpura, também cuidadosamente pregado." (MarQues, 1971, p. 212)
} 
equivale a um ritual longo que começa com o 'falecido' ainda vivo e dura o tempo de aproximação da morte ${ }^{12}$. O corpo é colocado numa vala alongada, recoberta de terra. Autoflagelação e choros são comuns nesse momento. Essa vala é todos os dias regada, para que a carne entre mais rapidamente em decomposição. Depois de quinze dias, cava-se a vala novamente para a retirada das partes apodrecidas e lavagem dos ossos, que são, então, transferidos para o centro da aldeia, onde a cerimônia é iniciada. Os ossos são pintados de tinta vermelha, feita de urucum e, depois, colocados numa cesta, que é pendurada na cabana do morto. Dias depois, os familiares e um membro da tribo levam a cesta para a lagoa mais próxima, em cujo trecho de maior profundidade é fincada numa estaca.

Para os Yanomâmi, diferentemente, a pintura no rosto na cor cinza é o começo de tudo. Os homens enfeitam-se com araxina (enfeites de penas de arara, papagaio, cujubim e mutum) por meio de braçadeiras e brincos, com folhas de tabaco na arcada dentária e lábio inferior e com horoma-ép (penugem branca em flocos) nos cabelos.

Esses ritos não encerram toda a diversidade brasileira, mas permitem evidenciar o quão diferentes eram os rituais anteriormente ao período de chegada dos portugueses.

12 É interessante notar que é o próprio indivíduo que, ao se sentir adoentado, avisa aos companheiros para iniciar o ritual de colar com resina uma porção de penas brancas sobre todo o corpo doente, que vai tomando a aparência de uma grande ave. Cantos e lamentos acompanham essa tarefa. 


\subsubsection{Um quadro paulistano}

Atualmente, a cidade de São Paulo possui 40 cemitérios, dos quais 22 são públicos ${ }^{13}$ e 18 particulares ${ }^{14}$ (cf. Rezende, 2008), mas nem sempre foi assim.

O mais antigo cemitério paulistano, criado a céu aberto, ficava no que hoje conhecemos como bairro da Liberdade, muito próximo ao Largo da Forca, onde escravos ou outros indivíduos que tivessem pendências com as leis de então eram enforcados. Ao centro do terreno, ficava a Capela de Nossa Senhora dos Aflitos. ${ }^{15}$ Trata-se do Cemitério dos Aflitos (ou dos Enforcados), criado no final do século XVIII (1774, cf. JaVovitch, 1996).

Ali, enterravam-se indigentes, escravos e supliciados. Funcionou até 1856, quando já estava em curso a criação do

13 Cemitério do Araçá (1887), Cemitério do Campo Grande (1953), Cemitério da Consolação (1858), Cemitério Dom Bosco (1971), Cemitério da Freguesia do Ó (1908), Cemitério de Itaquera (1929), Cemitério de Lajeado (1903), Cemitério da Lapa (1918), Cemitério de Parelheiros (1956), Cemitério da Penha (1910), Cemitério da Quarta Parada (1893), Cemitério de Santana (1897), Cemitério de Santo Amaro (1856), Cemitério São Luís (1981), Cemitério São Paulo (1926), Cemitério São Pedro (1971), Cemitério da Saudade (1960), Cemitério do Tremembé (1937), Cemitério de Vila Formosa (1949), Cemitério de Vila Mariana (1904), Cemitério de Vila Nova Cachoeirinha (1968).

14 Cemitério de Colônia (1829), Cemitério Gethsêmani (s/d), Cemitério Israelita do Butantã (1953), Cemitério Israelita de Vila Mariana (1923), Cemitério da Ordem Terceira do Carmo (1862), Cemitério da Irmandade do Santíssimo Sacramento da Catedral de São Paulo (s/d), Cemitério dos Protestantes (1862), Cemitério do Redentor (1924), Cemitério de Congonhas (1969), Cemitério da Paz (1965), Cemitério do Morumbi (s/d), Cemitério Parque das Cerejeiras (1993), Cemitério Parque da Cantareira (s/d), Cemitério Parque dos Girassóis (s/d), Cemitério Parque Jaraguá (s/d), Cemitério Parque dos Pinheiros (1997).

15 A igreja dos Aflitos ainda se mantém entre a Rua dos Estudantes e a Rua da Glória, no bairro da Liberdade. 
Cemitério da Consolação, ${ }^{16}$ mas, somente em 1883, foi demolido. Dedicou-se uma parte do cemitério aos protestantes (a partir de 1862). As ossadas do cemitério, acredita-se, ainda estejam no mesmo lugar, embora o terreno tenha sido loteado e vendido a particulares como podemos notar, nas fotos a seguir, pelo seu entorno.

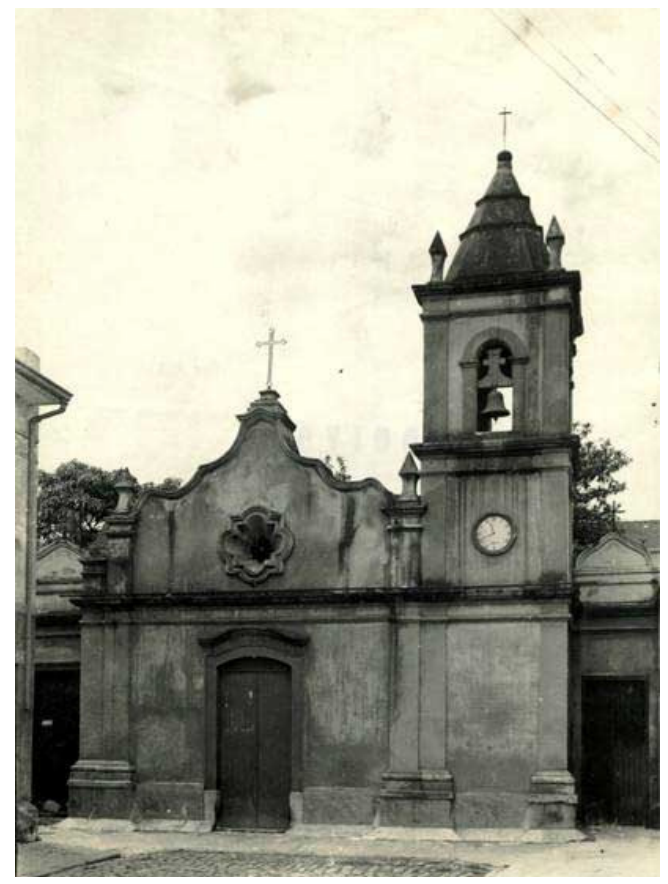

Antiga Capela de Nossa Senhora dos Aflitos (1939).

16 Marques (s/d, p. 179) apresenta informações conflitantes. Segundo ele, o cemitério da Consolação iniciou a construção em 1854 e foi aberto em 1858 em virtude da epidemia de varíola em São Paulo. 


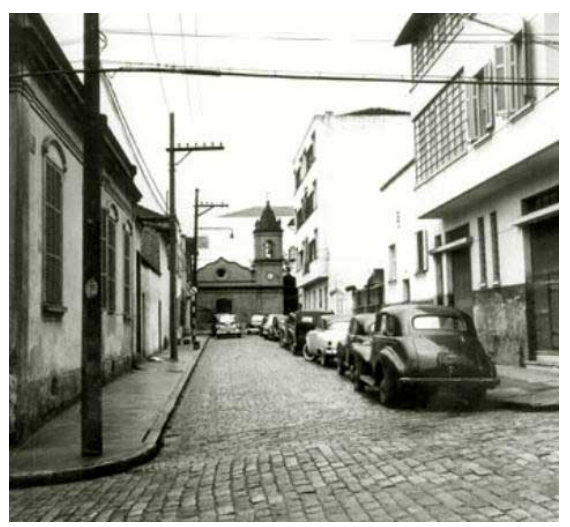

Rua dos Aflitos (1958). ${ }^{17}$

O Cemitério da Colônia (antigo Cemitério dos Alemães), situado até hoje em Parelheiros, foi o primeiro cemitério particular de São Paulo. Ele surgiu em decorrência da instalação de 200 imigrantes alemães não católicos na região Sul de São Paulo para trabalhar na colônia agrícola. No período da segunda Grande Guerra, permaneceu fechado, reabrindo somente mais recentemente (ano de 2000), depois de restaurado por uma associação de descendentes alemães.

17 Antiga Capela de Nossa Senhora dos Aflitos. Capela dos Aflitos, 1939 (photo20061105214016) e Rua dos Aflitos, 1958 (photo20070130154811) Fonte: [saudadesampa.nafoto.net]. Disponível em: http://www.girafamania.com.br/primitiva/cemiterios. htm>._Acesso em: 28 fev. 2014. 

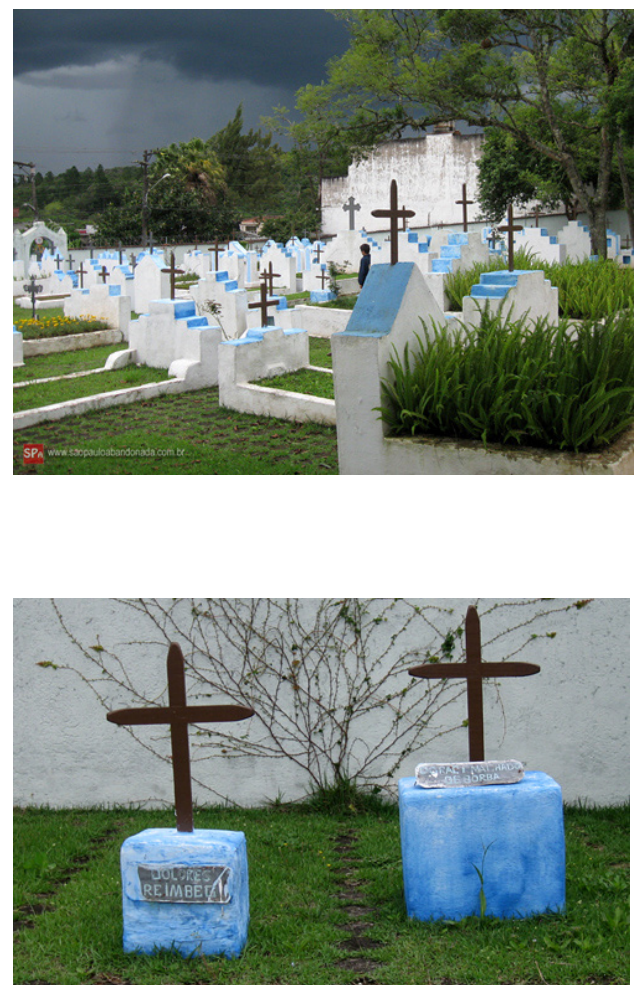

Cemitério da Colônia (Parelheiros). ${ }^{18}$

O cemitério de Santo Amaro foi inaugurado em 1856, uma solução à proibição régia de sepultamentos no interior de igrejas (Lei Régia de 01.10.1828). Hoje, é um cemitério público que atende a grande população, especialmente da zona Sul.

18 Disponível em: 〈http://www.saopauloantiga.com.br>. Acesso em: 28 fev. 2015. 

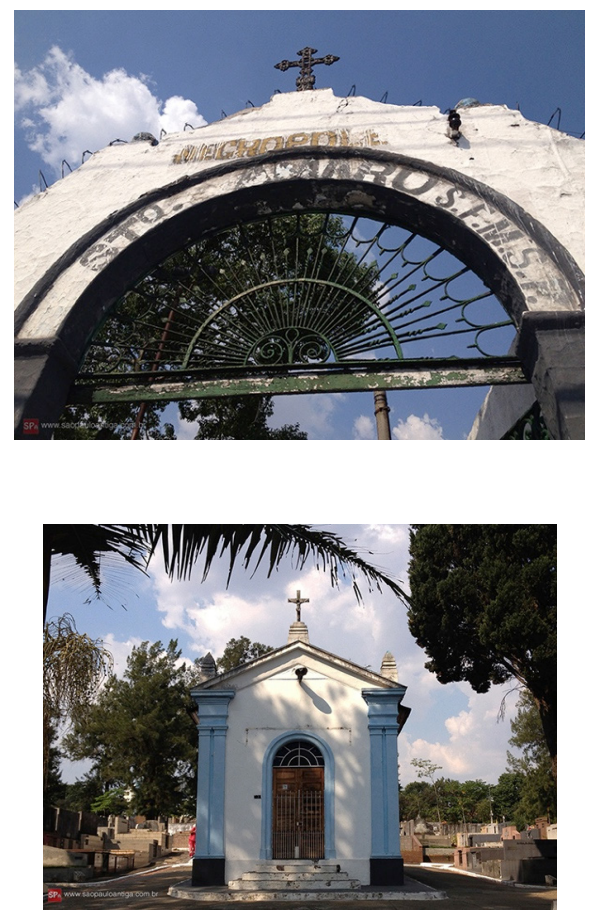

Cemitério de Santo Amaro. ${ }^{19}$

Ainda um outro cemitério esteve por anos contíguo ao Convento da Luz (desde 1845). ${ }^{20}$ Nele, seriam sepultadas religiosas e os capelães. Em 1851, metade do terreno foi cedido para um cemitério de estrangeiros católicos. Uma parte deste foi destinado aos estrangeiros não católicos, o que ficou conhecido à ocasião como o Cemitério dos Protestantes.

19 Disponível em: 〈http://www.saopauloantiga.com.br/cemiterio-de-santo-amaro/>. Acesso em: 28 fev. 2015.

20 Hoje é conhecido como Mosteiro da Luz. 

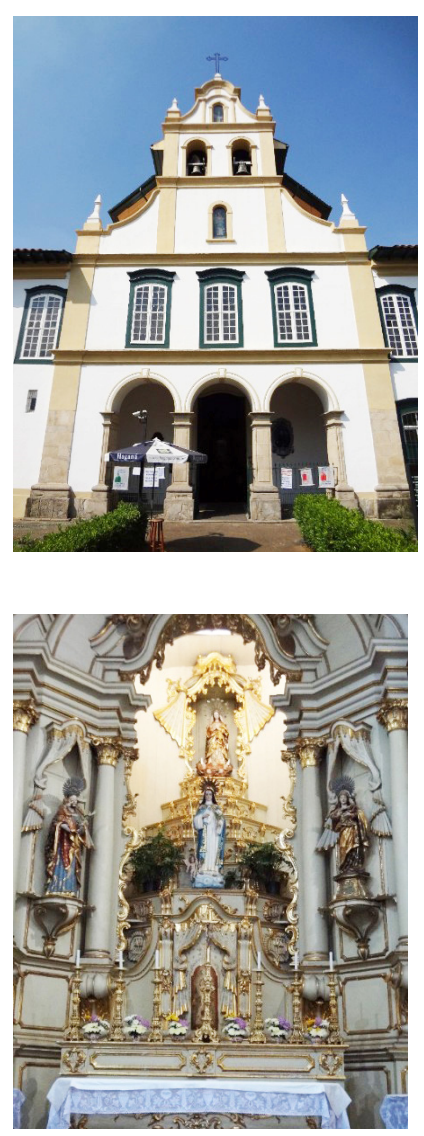

Mosteiro da Luz. ${ }^{21}$

Devido ao recorte metodológico que prioriza o cotejo de um desses cemitérios com outro de Macau, em momento oportuno trataremos do cemitério da Consolação, que teve uma função primordial na organização da cidade de São Paulo. Sua

21 Disponível em: 〈http://www.mosteirodaluz.org.br/category/galeria/fotos/>. Acesso em: 28 fev. 2015. 
fundação auxilia a compreender as razões para que uma área tão grande no centro de São Paulo fosse transformada em cemitério e, ao mesmo tempo, fornecerá informações igualmente importantes para o conhecimento da cultura dos habitantes do primeiro decênio do século XX. Antes, porém, visitaremos o espaço da China e de Macau.

\subsection{Tradição chinesa relativa à morte}

Tratar da China pressupõe lidar com uma extrema diversidade cultural. Se considerarmos, por exemplo, sua história milenar, sua diversidade (tecnicamente, são identificadas ao menos 56 etnias), sua dimensão geográfica, suas variadas tradições filosófico-religiosas (taoísmo, budismo, confucionismo, xamanismo), sua contemporaneidade política e tecnológica e seus contrastes (centros cada vez mais urbanos e espaços mais rurais ${ }^{22}$ ), seremos levados ao reconhecimento de um processo de variação e de mudança nos rituais fúnebres praticados no País do Meio. Assim é que oferecemos aqui um olhar mais genérico, mas adequado aos propósitos deste texto.

Esse espaço asiático prevê diferenças de tratamento ao morto a depender do nível social, estado civil e causas que motivaram a morte. Segundo essa concepção, e em função da profunda hierarquização entre gerações, os mais velhos não têm obrigações de respeito pelos mais jovens, o que faz com que o enterro de um mais jovem seja iniciado na casa funerária e não no lar, como aconteceria com os mais velhos. Nessa perspectiva,

22 Matéria do jornal Epoch Times, da China, revela esse contraste de atitudes ao relatar o caso de um idoso que, aos 92 anos, fugiu de casa para não ser cremado. Retornou à sua vila natal para ter direito a um sepultamento apropriado segundo sua concepção. 
os pais não fazem preces para os filhos e, como cabe aos filhos fazerem o ritual aos pais, os mais jovens ficam sem alguém que assuma essa função. É por isso que bebês e crianças não necessariamente têm rituais fúnebres. O silêncio é, salvo engano, a regra mais adotada nesses casos.

Assim como vimos com algumas tribos brasileiras, os preparativos para o funeral começam também antes mesmo que a morte ocorra:

Quando morre alguém na família, todas as estátuas dos deuses na casa são cobertas com um papel vermelho e retiram-se os espelhos do lugar. Acredita-se que se alguém vê o reflexo do caixão em um espelho, em um breve tempo haverá uma morte na própria família. Uma tela branca é colocada sobre a porta da casa e coloca-se um gongo à esquerda da entrada se o falecido for homem, e à direita se for mulher.

Antes de colocá-lo no caixão, se limpa o cadáver com uma toalha molhada, passa-se talco nele e veste-se com sua melhor roupa. Veste-se o corpo completamente, inclusive os sapatos, e faz-se a maquiagem se for mulher, porém nunca o vestem com roupas vermelhas (isso faria que ele se transformasse num fantasma). Em geral, se usam as cores preta, marrom ou azul. Antes de colocar o cadáver no caixão, cobre-se sua face com um pano amarelo e o corpo com um pano azul. (ЕРоcH Times, 2012) $)^{23,24}$

23 Atualizado em 11/09/2012 às 23h19. Acesso em: 28 fev. 2015.

24 Disponível em: https://www.epochtimes.com.br/funerais-tradicionais-chineses-um-ritual-profundo-trocado-pela-cremacao-2/\#.WcK7yNOGO-U Acesso em: 20 set. 2017. 
Também o lugar do velório dependerá do lugar em que a pessoa morreu. Caso a pessoa tenha morrido dentro de casa, o caixão permanecerá nesse local, mas, se a morte ocorreu fora, então o caixão deverá permanecer no jardim, em suportes e numa posição adequada ${ }^{25}$. É típico que haja comida para o falecido e que seu pente seja dividido em duas partes (uma vai para o caixão e outra, para a família). Não se pode usar joias ou vestidos vermelhos. Até hoje, os mais velhos impedem que os netos do falecido cortem o cabelo por 49 dias após o enterro e as cores das roupas também devem ser diferenciadas. ${ }^{26}$

Durante todo o velório, queimam-se incensos e papel "joss" (papel especial usado nesses rituais), e "dinheiro de oração" para prover ao falecido ingressos suficientes para a sua vida além-túmulo. Também é comum que as pessoas joguem jogos de azar durante o velório na casa do falecido, o que os faz distraírem-se da dor da perda.

Como no Ocidente, os rituais ligados à morte mantêm os simbolismos e a hierarquia da sociedade. Assim, a forma de ritualizar expressa a posição que ocupa o morto nas relações de poder. Como podemos depreender da imagem a seguir, enterrar os mortos em colinas também simboliza uma hierarquização. A construção em semicírculo, de forma paralela, representa a ideia de que o céu é redondo.

25 O caixão é posto sobre suportes a uns $30 \mathrm{~cm}$ de distância do solo, e a cabeça do caixão põe-se de frente para a parte interior da casa. As coroas, presentes e retratos ou fotos do falecido colocam-se na cabeceira do caixão. O caixão não é fechado durante o velório. 26 Crianças e noras vestem-se de preto, uma cor simbolizadora da angústia, e usam chapéus. Os netos vestem azul e os bisnetos azul claro. Genros utilizam cores mais chamativas e brilhantes, como o branco, por não integrarem o núcleo central da família. 


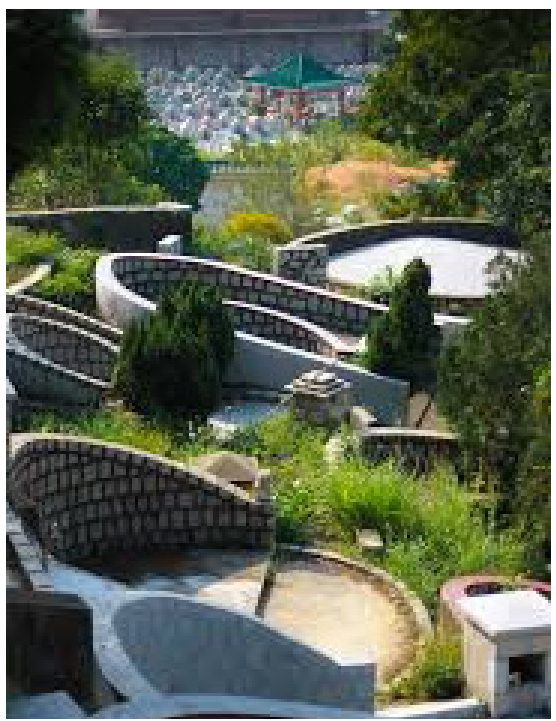

Cemitério Budista. ${ }^{27}$

Mais recentemente, grandes mudanças foram operadas nesses rituais. Nos centros urbanos e cada vez mais em regiões circunvizinhas a eles, os mortos têm sido cremados. O que surge desses rituais, não como uma constante ou um traço fixo chinês, mas como uma tendência bastante evidente, é uma relação familiar extremamente forte proveniente desse culto ancestral que se mantém no dia a dia de Macau, mesmo nas ruas, seja a partir do funeral, seja a partir dos sacrifícios. No caso do funeral, o milenar ritual de o morto levar os seus pertences ou, ao menos, ter a possibilidade de os ter na outra vida, continua também nas práticas cotidianas de queima de papéis.

27 Disponível em: <http://macauelogoali.blogspot.com.br/2011/12/cemiterio-budista. html>. Acesso em: 30 jun. 2015. 


\subsubsection{A morte entre os habitantes de Macau}

Macau, hoje conhecida como Região Administrativa Especial de Macau (RAEM), foi crescendo ao longo do século XX em direção às demais ilhas próximas, duas das quais incorporadas ao seu território (Coloane e Taipa). Nesse espaço geográfico, circulam, em grande maioria, chineses da China Continental, com hábitos e costumes diferentes, em grande medida, da população local de Macau, 'colonizada' por portugueses até 1999.

A chegada dos costumes católicos portugueses ocorreu no século XVI, gradativamente incluindo pessoas chinesas a esse campo de rituais. Um grupo especialmente citado é o dos macaenses, filhos da terra ${ }^{28}$.

Assim como há muito tempo há a escola, o cinema, o hospital, o bairro, a freguesia mais ou menos tipicamente chinesa, também, desde muito tempo, há o cemitério mais ou menos chinês. Os ritos funéreos, em Macau, realizam-se em 18 cemitérios $^{29}$. Todos eles são regidos pelo artigo $6^{\circ}$, Regulamento

28 Até bem recentemente, hoje cada vez menos, uma distinção entre macaenses, chineses e macaenses $100 \%$ era prioritária para o acesso aos serviços públicos diversos. Cada vez menos, há essa preocupação, que foi se alterando desde o handover, em 1999, quando a China retomou o poder sobre Macau.

29 Cemitérios públicos: Cemitério de S. Miguel Arcanjo (Península de Macau); Cemitério de Nossa Senhora da Piedade (Península de Macau); Cemitério do Carmo da Taipa (Ilha da Taipa); Cemitério Sá Kong da Taipa (Ilha da Taipa); Cemitério Municipal de Coloane (Ilha de Coloane); Cemitério Va Ian de Coloane (Ilha de Coloane). Disponível em: <http://www. iacm.gov.mo/p/facility/introduction/grave>. Acesso em: 20 set. 2017.

Cemitérios particulares: Cemitério Novo de Mong Há (Península de Macau), Cemitério dos Parses (Península de Macau), Cemitério Protestante (Península de Macau), Cemitério da Mesquita (Península de Macau), Cemitério Kai Fong (Ilha da Taipa), Cemitério Hao Si (Ilha da Taipa), Cemitério Pao Choc (Ilha da Taipa), Cemitério Ka Ho (Ilha de Coloane), Cemitério Son I (Ilha de Coloane), Cemitério Kok Ip (Ilha de Coloane) e Cemitério Hac Sa (Ilha de Coloane). Disponível em: <http://bo.io.gov.mo/bo/i/2003/47/regadm37.asp?mobi- 
Administrativo $\mathrm{n}^{\circ} 37 / 2003$, que orienta o respeito e a tranquilidade nos cemitérios. ${ }^{30}$

Um dos cemitérios mais visitados em Macau é o Protestante, justamente por estar em um espaço privilegiado de turismo, no bairro Santo Antônio:
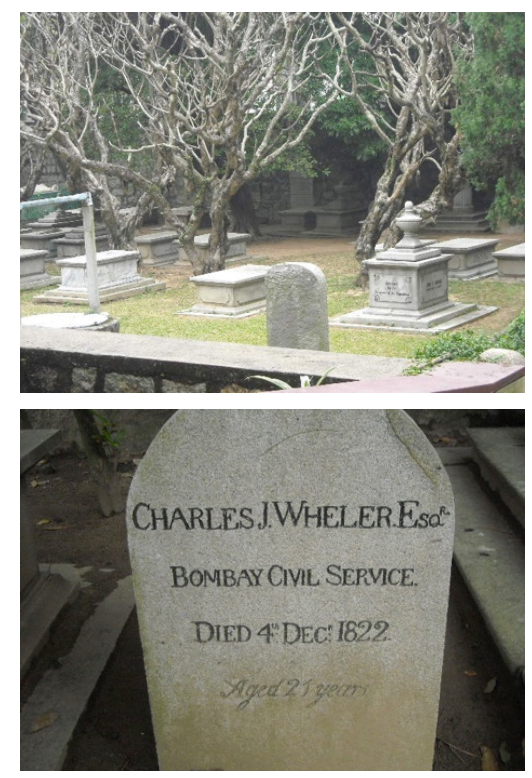

Cemitério Protestante. ${ }^{31}$

le=1>. Acesso em: 20 set. 2017. Há, ainda, o United Chinese Cemetery (o Cemitério Budista). 30 "1. Nos cemitérios é proibido: 1) Proferir palavras ou praticar actos adequados a impedir ou perturbar, ainda que sem ameaça, o exercício do culto de religião, bem como a realização de cerimónia fúnebre; 2) Proferir palavras ou praticar actos adequados a ofender o sentimento de reverência dos vivos para com os mortos; 3) Fazer publicidade comercial ou exercer a venda ambulante; 4) Exercer a mendicidade.

2. Depende de autorização prévia da entidade gestora do cemitério, a captação de fotografias e a realização de filmagens que tenham finalidades comerciais, bem como reportagens dentro do cemitério." Disponível em: <http://bo.io.gov.mo/bo/i/2003/47/ regadm37.asp?mobile=1>. Acesso em: 20 set. 2017.

31 Arquivo pessoal, fotografia de 2010. 
Esses cemitérios seguem uma estética diversa a depender do grau de entrosamento com a sociedade portuguesa da Macau 'colonial', mas uma coisa é certa: cada vez mais, os habitantes chineses de Macau foram aderindo ao féretro (e a outros rituais) ocidental durante o século XX por razões diversas. Isso justifica por que não se veem símbolos católicos, como harpas, anjos e cruzes no cemitério Protestante, tão apartado da cultura predominante local no século XX.

Podemos dizer que o Cemitério São Miguel Arcanjo, um cemitério público encrustado entre o bairro de São Lázaro e o Centro, é um cemitério tipicamente macaense. Ao longo do século XX, foi incorporando a nata da sociedade e, depois, outros tantos habitantes em seus estreitos espaços.

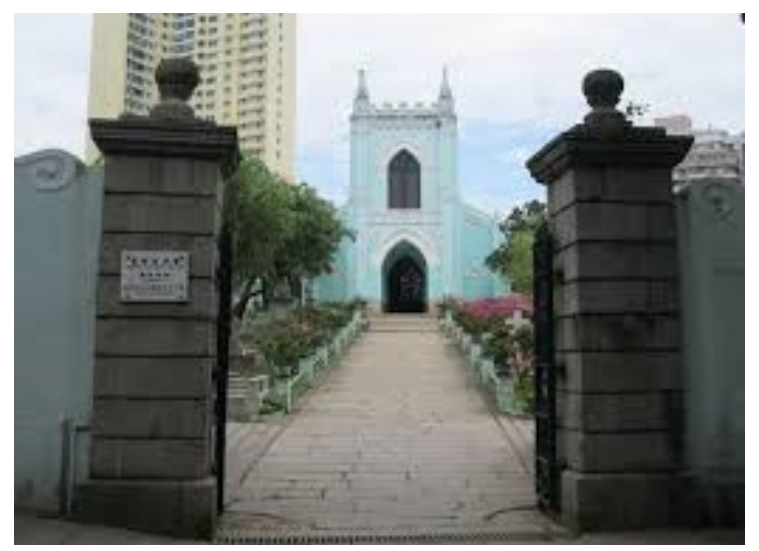

Cemitério de S. Miguel Arcanjo. ${ }^{32}$

32 Disponível em: <http://www.iacm.gov.mo/p/facility/introduction/grave>. Acesso em: 30 jun. 2015. 
Outros cemitérios marcam a multiculturalidade, a multifiliação filosófico-religiosa, como o Cemitério dos Parses (Península de Macau), o Cemitério da Mesquita (Península de Macau) e o conhecido Cemitério Budista (Ilha de Taipa).

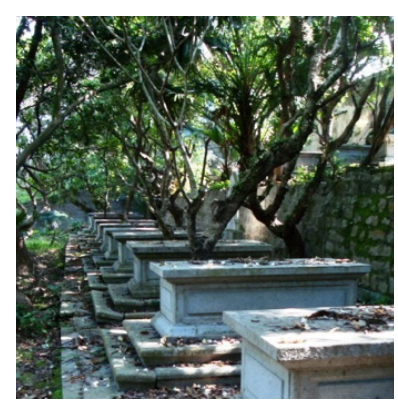

Cemitério dos Parses ${ }^{33}$

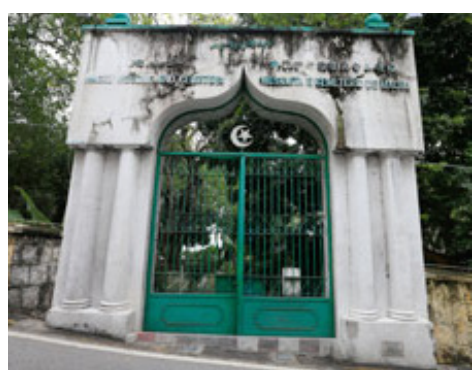

Cemitério da Mesquita ${ }^{34}$

33 Disponível em: <http://macauantigo.blogspot.com.br/2014/02/cemiterio-dos-parses. html>. Acesso em: 30 jun. 2015.

34 Disponível em: <http://pt.macaotourism.gov.mo/sightseeing/sightseeing_detail. php?c=8\&id=315\#.WoQjF0xFy71>. Acesso em: 30 jun. 2015. 


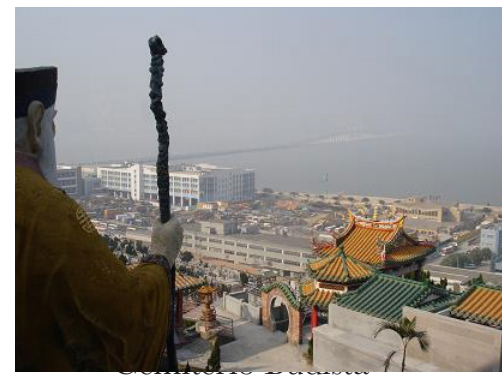

A presença de diversos grupos étnicos em Macau, muitas vezes com presença social muito discreta, fica marcada pelos cemitérios. Como podemos ler no site da Direç̧ão dos Serviços de Turismo de Macau a respeito do Cemitério da Mesquita (Península de Macau), "As sepulturas, algumas das quais com mais de cem anos, atestam uma vez mais a tolerância multicultural de Macau, ao longo dos séculos, e servem de prova histórica da ligação islâmica ao território" ${ }^{36}$.

Como um espaço multiétnico que herda culturas de povos asiáticos e não asiáticos milenares, diferentes rituais de morte também têm lugar em Macau. Os cemitérios, entretanto, como espaços de rituais fúnebres, são espaços privilegiados que espelham toda essa diversidade cultural.

35 Disponível em: <http://www.itravelnet.com/photography/asia/macau/taipa/united-chinese-cemetery.html>. Acesso em: 30 jun. 2015.

36 Disponível em: <http://pt.macautourism.gov.mo/sightseeing/sightseeing_detail.php?c=8\&id=315\#.VZLgYxNViko>. Acesso em: 30 jun. 2015. 


\section{Viver é se manter vivo na memória}

Philippe Ariès (2003) afirmou, em algum momento de sua produção, que a morte foi banida das preocupações do homem ocidental do século XX, razão pela qual acabou por ser marginalizada. Essa marginalização teve como consequência a criação de um tabu em torno do tema e também a terceirização das relações com a morte (cf. Consorte, 1983; QueIroz JR., 1983; Santos, 1983).

Uma das trajetórias da morte, no Ocidente, tem início com sua aceitação na Idade Média, quando todo o ritual era socializado, e a despreocupação com o destino do corpo era ge$\mathrm{ral}^{37}$. Com o século XII, o 'mundo pleno' da Europa Medieval, as mudanças já estão agindo, lentamente, no sentido de que a morte passe a ser vista com maior dramaticidade, individualidade: as sepulturas vão se tornando individualizadas, identificadas, dentro das igrejas ou em capelas mortuárias ${ }^{38}$. O homem vai

37 Segundo os autores consultados, os corpos eram enterrados, na mesma vala, algumas vezes no interior da igreja, outras vezes em volta desta, sem o cuidado de identificação pessoal.

38 Segundo informações extraídas no site da Assembleia Legislativade São Paulo, que, por sua vez, recolheu em Antônio Egydio Martins, o serviço de enterramento dentro das igrejas era realmente dramático: "O serviço de enterramento de cadáveres nas igrejas ou nos cemitérios contíguos às mesmas era feito, antigamente, por pretos africanos, que, à proporção que iam pondo terra sobre o cadáver, socavam este com uma grossa mão-de-pilão, contando o seguinte: Zóio que tanto vê. Zi boca que tanto fala. Zi boca que tanto zi comeu e zi bebeu. Zi cropo que tanto trabaiô. Zi perna que tanto andô. Zi pé que tanto zi pisô. E assim iam eles cantando esses e outros despropósitos até acabarem de cobrir com terra a sepultura, sendo que, em conseqüência de quase todas as irmandades possuírem um só caixão, o cadáver de qualquer dos seus irmãos era sepultado sem o mesmo caixão, voltando este, depois de enterrado o cadáver, para a sacristia da igreja, na qual ficava guardado até o dia em que novamente era pedido para servir a algum irmão falecido de uma daquelas irmandades. Os moradores das proximidades das mesmas igre- 
descobrindo a "morte de si mesmo" e esta adquire características eróticas e de morbidez.

Com o século das Luzes e do Barroco, a morte começa a ser dramatizada, exaltada. Toma sentido a "morte do outro", e a morte assume o significado de ruptura, passa a ser indesejável, embora admirada pela beleza que lhe dá o romantismo. A morte do século XIX é acompanhada no leito moribundo, por ritos e manifestações de choros, gestos dramáticos, uma afetividade macabra, que Ariés explica pela religião emotiva do catolicismo romântico ou do pietismo protestante ${ }^{39}$. "Surge o culto contemporâneo com túmulos individuais ou familiares, da sepultura como propriedade particular e perpétua e o culto da saudade, com as periódicas peregrinações aos cemitérios" (MARCílio, 1983, p. 63). É a morte suscitando vida.

Segundo Marcílio (1983), a civilização urbana e industrial altera o quadro funerário. Mais especificamente a partir de 1950, não se morre mais em casa, mas no hospital. A morte é algo escondido, as pessoas são desenganadas, os médicos se

jas e cemitérios, por causa de tais cantigas e socamentos de cadáveres, ficavam bastante amedrontados com isso, ouvindo, a alta hora da noite, naqueles lugares, certo rumor que lhes parecia estarem cantando e socando, tratando, logo que podiam, de mudar dos mesmos lugares para outros pontos da Cidade mais distantes das igrejas e cemitérios." [sic]. 39 "No período colonial foi escassa a presença de protestantes no Brasil. Somente no início do século 19, após a transferência da corte portuguesa para o Rio de Janeiro, o protestantismo começou a inserir-se de modo mais amplo na sociedade brasileira. Essa inserção teve duas fases bem definidas. Inicialmente, a partir de 1810, houve o surgimento do chamado 'protestantismo de imigração', ou seja, todos os protestantes existentes no Brasil eram estrangeiros que para cá tinham vindo como imigrantes, especialmente ingleses (anglicanos) e alemães (luteranos). Posteriormente, surgiu o 'protestantismo de missão', como resultado do trabalho de missões européias e norte-americanas entre os brasileiros. Essa modalidade implantou-se definitivamente a partir de 1855, com a chegada do Rev. Robert Reid Kalley, seguido, em 1859, pelo Rev. Ashbel Green Simonton.” (Matos, s/d, s/p.) 
calam diante do processo de chegada da morte ${ }^{40}$, os familiares fazem o mesmo. A partir desse período, as manifestações que tornem presente a morte ocorrida são condenadas e, por isso, vão caindo em desuso na sociedade. Surge com força a incineração ou cremação, muito mais adotada pela camada de elite e, depois, pelos populares.

Não se deve perder de vista que, com a cremação, desaparecem os restos mortais que não serão mais cultuados em cemitérios, e toma seu lugar o ritual de espalhar as cinzas, que se dispersam. Nessa dispersão, simboliza-se a dissipação da dor da perda, o minimizamento do sofrimento. E a morte, como no ritual anterior, representa a eternização da vida, pois servirá de adubo ou de alimento a outra vida, e a vida ressurgirá em vida, numa outra vida. E a metáfora se faz.

\subsection{A construção da memória e da saudade}

Outro elemento que compõe o cenário como espelho é a língua, em suas modalidades falada e escrita, a qual se presta como espaço de vazão das sensações humanas diante da morte. Essa vazão se mostra em ditos populares, em frases feitas de condolências, e especialmente em epitáfios.

Uma expressão italiana de alta recorrência diz que, para receber elogios, o melhor meio é morrer. Esse dito revela muito sobre o comportamento das pessoas diante da morte. As últimas

\footnotetext{
40 De acordo com Jacques Ruffié (1988, p. 216), o médico enfrenta a morte de seus pacientes de um modo diferente: "Primeiro existe a morte do outro, do doente. Eu a vivi, acabrunhado, como médico, sem jamais aceitá-la (sic), sobretudo nos jovens, no estudante que não voltará ao colégio, na mãe que vai deixar os seus filhos, no pai que já não sustentará o lar. Pode acontecer que sintamos esses falecimentos prematuros como uma injustiça revoltante, e que meçamos por eles toda a precariedade da vida."
} 
palavras que ficam sobre o morto, invariavelmente num epitáfio, garantem que não há um único traço de maldade ou de ressentimento que envolva os mortos. Se os mortos pudessem ler os epitáfios que seus herdeiros lhes consagram, achariam que entraram no cemitério errado.

Os epitáfios fazem com que as mensagens sejam marcas de saudades e de profunda lacuna que se abre como uma ferida entre os membros de uma família. No entanto, quando redigidos pelos próprios futuros mortos, ganham em lirismo. É o que lemos nos epitáfios elaborados por célebres autores, como João Cabral de Melo Neto ${ }^{41}$, Charles Baudelaire ${ }^{42}$, André Malraux ${ }^{43}$ e Oswald de Andrade ${ }^{44}$.

\subsubsection{Por meio de epitáfios: homenagens e sentimentos ecoados}

A história dos epitáfios e das inscrições tumulares entrecruza-se quanto a soluções familiares encontradas. É raro que o próprio morto tenha pensado em deixar algo para ser colocado

41 Nesta terra ninguém jaz, | pois também não jaz um rio | noutro rio nem o mar | é cemitério de rios $\mid$ Nenhum dos mortos daqui $\mid$ vem vestido de caixão. |Portanto, eles não se enterram | são derramados no chão.|| Vêm em rêdes (sic) de varandas | abertas ao sol e à chuva.|Trazem suas próprias moscas.| O chão lhes vai como luva.|| Morto ao ar-livre, que eram, | hoje à terra livre estão. | São tão de terra que a terra $\mid$ nem sente sua intrusão. João Cabral de Melo Neto (1965, p. 128).

42 Ó Morte, velho capitão, é tempo! Às velas! | Este país enfara, ó Morte! Para a frente!| Se o mar e o céu recobre o luto das procelas, | Em nossos corações brilha uma chama ardente! (Charles Baudelaire, In: Le voyage).

43 A morte transforma uma vida em destino. Malraux-

44 Eu sou redondo, redondo $\mid$ Redondo, redondo eu sei $\mid$ Eu sou uma redond'ilha $\mid$ Das mulheres que beijei.

Vou falecer do Oh! Amor $\mid$ Das mulheres de minh'ilha $\mid$ Minha caveira rirá ah!ah!ah!| Pensando na redondilha (Oswald de Andrade, 1976) 
em seu túmulo. A família é quem decide o que fica exposto, às vezes elaborando algo criativo e totalmente personalizado ao indivíduo que morreu, motivado pelo sofrimento vivenciado com a perda. Desde o início do século XX até meados desse mesmo século, escolhia-se entre frases prontas aquilo que melhor agradava à familia do morto. Mais recentemente ainda, nada se inscreve. A morte tornou-se efetivamente o silêncio familiar, o luto verbal.

A palavra epitáfio ${ }^{45}$, do grego epitáphion, entrou no português pela língua latina (epitaphiu), um substantivo masculino que remete a quatro acepções: 1. Inscrição tumular; 2. Por extensão, lápide ou tabuleta com epitáfio; 3. Elogio fúnebre; 4. Espécie de poesia satírica (em geral uma quadra) feita sobre um vivo como se se tratasse de um morto (Holanda, 1999, p.780). Vejamos alguns epitáfios:

Aqui jaz hum que em outro tempo foi grande varom Sabedor e muito eloquente e avondado e rico e agor He pequena cinza encarrada em este moimento E com el jaz hum seu sobrinho dos quaes hum Era já velho e o outro mancebo e o nome do Tio Sesnando e Pedro avia nome o Sobrinho (Epitáfio do Conde D.Sesnando, apud LeOni, 1858) ${ }^{46}$

45 De acordo com a Encyclopaedia Britannica (1768, p. 661-662), as mais antigas inscrições tumulares, escritas, são dos antigos egípcios em sarcófagos e caixões. Em Esparta, os epitáfios eram destinados a herois de guerra, em Atenas, a todos indiscriminadamente. No Museu Britânico, há inscrições de várias urnas, com pouca variação.

46 "Ainda que na lingua vulgar se não empreguem hoje todas as formas da construcção latina, não é, todavia, possivel deixar de reconhecer essas formas em nossas antigas escripturas, onde apparece a mais completa analogia de syntaxe. - Para prova citaremos o Epitaphio do Conde D. Sesnando, que se conserva 'numa das paredes de Sé Velha de 
Os epitáfios ${ }^{47}$, que são as inscrições tumulares, ocupam um papel antigo na história do homem, sendo as mais antigas localizadas nos sarcófagos e caixões egípcios. As já decifradas continham todas a mesma forma: começavam por uma reza dedicada a uma divindade e depois ao nome e função do falecido na sociedade (cf. Encyclopaedia BRITANNICA, 1768, p. 661-662). Nos dois cemitérios selecionados para esse levantamento, um em São Paulo (Cemitério da Consolação) e outro na RAEM (São Miguel de Arcanjo), encontramos epitáfios com características similares, o que nos conduz à ideia de uma interferência cultural portuguesa, pois distanciam-se dos costumes locais anteriores à chegada portuguesa. Vejamos os quatro padrões que identificamos:

a) epitáfios como simulacro da fala do morto

Eu vou para Deus. Mas não| esquecerei aqueles a quem | amei na terra. |Sto. Agostinho | Eterna saudade da sua | esposa, filhos e família | À saudosa memória | de| Luís Braga | Nasceu em 02-07-48 | Faleceu em 14-01-84 (Cemitério de S.Miguel Arcanjo - Macau)

Coimbra, e que mostrando pela construcção ser trasladado de outro escripto em latim, está, comtudo, no estilo e gosto de nossa antiga linguagem. J. Pedro Ribeiro, ao passo que não duvida da procedencia latina d'esta inscripção, confessa com bastante ingenuidade para um partidario do systema celtico, que pela phrase indica ser do tempo de D.João $1^{\circ}$ até D.Manuel. Vid. Dessert. Chron. T. 1º p. 193, nota.”' (Leoni, 1858).

47 Em cada cultura, o epitáfio se presta a um fim específico. Na Esparta, eram destinados a heróis de guerra somente; em Atenas, tinham uso geral; em Roma, registravam fatos importantes, ao contrário do que ocorria na Grécia Antiga. 
José Tavares | de Miranda | 16-11-1916. + 20-08-1992 | "Maior do que a lua, | do que o sol e as | outras estrelas é o | lampião que alumia | a esquina da rua | onde nasci.” (J.T.M.) (Cemitério da Consolação - São Paulo)

b) epitáfios como síntese de vida e dos feitos

Aqui jaz | Francisco Antonio Fernandes | Natural de Chander de Salsete - Gôa | Cavalleiro da antiga ordem de Torre e Espada| Nasceu aos 4 d'outubro de 1818| Falleceu n'esta cidade aos 20 de março de 1882| R.I.P. | (Cemitério de S.Miguel Arcanjo)

Viveu, sofreu e morreu | amando Jesus. | 19-10-1918. +21-12-1930 (Cemitério da Consolação)

c) epitáfios como mensagens de saudades na voz de familiares

Esta lousa | encobre as cinzas | d'uma mulher virtuoza e| d'uma may carinhosa|Emilia Maria | D'Encarnação e Silva | nasceo aos 17 de mayo de | 1820| E voou para o eterno | em 27 do mesmo mez do anno | de 1864 |É dos sentidos filhos | esta homenagem (Cemitério de S.Miguel Arcanjo)

Ao adorado Álvaro. | Meu inesquecível filho, carinhoso e | santo. | Faz dois annos que morreste, filho. | Dois longos annos sem jamais te ver! | Filho querido, que deixaste o mundo, I e os meus carinhos, para aqui jazer! | Oh! Tu deixaste tua mãe tão cedo! | Trocaste a vida pelo frio chão. | Eu só queria que pudesse ainda 
| cingir-te, filho, junto ao coração! | Eu só queria que pudesse, filho, | voar alegre para a eternidade, | e lá risonha, como branca estrella, | seguir-te comtigo pela immensidade! | 25-09-1921. | Tua desventurada mãe, de $\mid$ eterna saudade pungida. (Cemitério da Consolação)

\subsubsection{Esculturas: emoções e sentimentos pela arte}

Nos dois cemitérios públicos que selecionamos para estudo neste texto, identificamos outra forma de escoar os sentimentos e emoções que envolvem toda a família e os visitantes dos cemitérios nesse sentimento de esquiva da morte: as esculturas. Tanto no Brasil quanto na RAEM, as formas de manifestação da arte são muito parecidas, e os símbolos utilizados para manifestar a saudade e a homenagem são derivados da interpenetração da cultura 'colonial'.

\subsubsection{A cruz}

Entre os cristãos, a cruz tem um significado forte e redentor. Durante o século XX, todo católico carregava consigo uma corrente (ou cordão) ao pescoço com esse símbolo pendurado. As freiras, invariavelmente, usam um anel em que uma cruz está impressa, marcando a entrega de sua vida aos propósitos de Jesus.

Historicamente, a crucificação era uma forma romana de punição e de tortura a pessoas que fugiam de algum modo às leis romanas. Jesus Cristo, filho de Deus para os católicos (os cristãos), foi crucificado e desse advento surge metonimicamente o espaço do martírio como o símbolo que une os cristãos. 


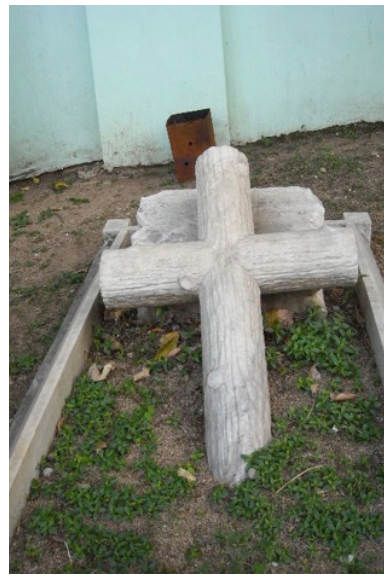

Cemitério S. Miguel Arcanjo. ${ }^{48}$

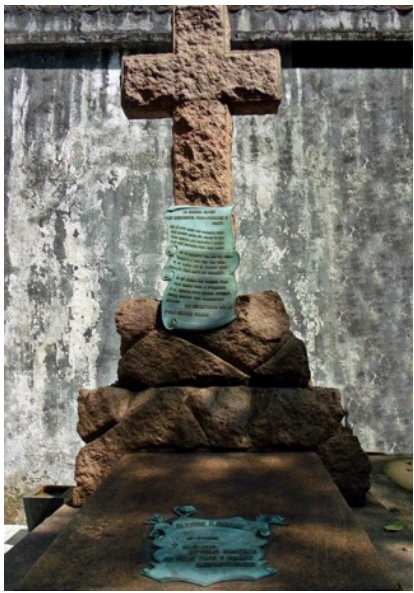

Cemitério da Consolação. ${ }^{49}$

48 Arquivo pessoal. Registro em 2010.

49 Arquivo pessoal. Registro em 2010. 
Muitas são as expressões que incorporam os valores semânticos da cruz para construir outras expressões cristalizadas na língua. Vejamos algumas delas:

Quadro I: Síntese de usos e equivalências - cruzes

\begin{tabular}{|c|c|}
\hline Expressão & Sentido equivalente \\
\hline $\begin{array}{c}\text { Estar entre a cruz e a } \\
\text { espada }\end{array}$ & sentir-se em dúvida entre duas coisas importantes \\
\hline $\begin{array}{c}\text { Estar entre a cruz e a } \\
\text { caldeirinha }\end{array}$ & sentir-se em dúvida entre duas coisas importantes \\
\hline Carregar uma cruz & Fazer o serviço pesado ou tarefas mais difíceis \\
\hline Levar a cruz ao calvário & Esforçar-se por concluir uma ação difícil \\
\hline Fulano é minha cruz & Ser um peso demasiado na vida de outra pessoa \\
\hline Cruz credo! & Interjeição que significa repúdio \\
\hline
\end{tabular}

\subsubsection{Anjos celestiais}

Anjos simbolizam um ser puramente espiritual (cristianismo, judaísmo e islamismo), e essa pureza invariavelmente é associada às crianças (inocência) e às moças (virgindade). 


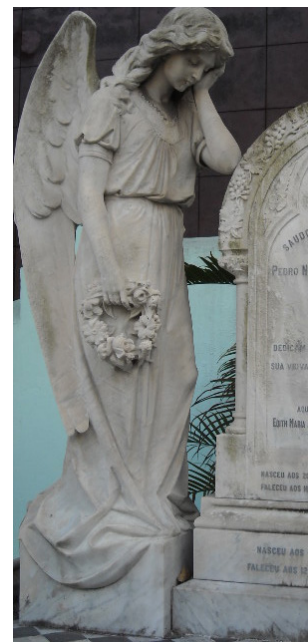

Cemitério S.Miguel Arcanjo. ${ }^{50}$

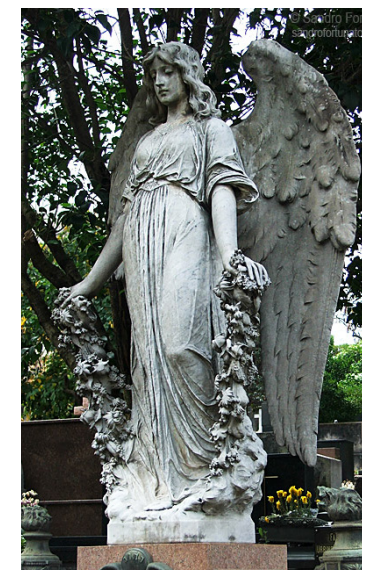

Cemitério da Consolação. ${ }^{51}$

50 Arquivo pessoal. Registro em 2010.

51 Arquivo pessoal. Registro em 2010. 
Quadro 1I: Usos e equivalências - Anjos

\begin{tabular}{|c|c|}
\hline Expressão & Sentido equivalente \\
\hline Ser um anjo & Ser bom, ser gentil, auxiliar \\
\hline Ser um anjinho & Não ser travesso \\
\hline Anjo da guarda & Protetor, segurança \\
\hline Dormir como um anjo & Dormir profunda e tranquilamente \\
\hline Cantar como um anjo & Cantar afinadamente \\
\hline
\end{tabular}

\subsubsection{Mulheres em sofrimento/desolação}

As mulheres são as que geram uma nova vida em qualquer sociedade, pelo menos numa perspectiva mais tradicional. Homens e mulheres, salvo engano, são seres que experienciam o sofrimento ao longo da vida e, como efeito, da perda por morte.

Nos cemitérios, no entanto, é bastante incomum encontrar imagens masculinas conotando desolação e sofrimento. Homens enfrentam a morte com força e coragem, pelo menos é o que os semblantes em esculturas de cemitérios nos permitem ler. Mulheres representam melhor o sofrimento sem fim, a desolação e o luto. Na maioria das culturas, há alguma diferença entre a mulher que perde o marido e a mulher que perde qualquer outro parente da família. Também há diferença entre a mulher que perde o marido e o marido que perde a mulher. As mulheres culturalmente marcam essa passagem na vida com roupas, costumes e hábitos diferentes, talvez por isso sejam as imagens perfeitas para a marca do sofrimento nas estátuas dos cemitérios que visitamos. 


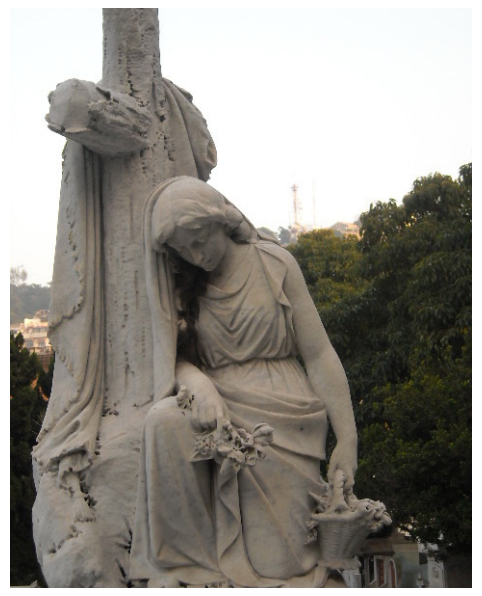

Cemitério S.Miguel Arcanjo. ${ }^{52}$

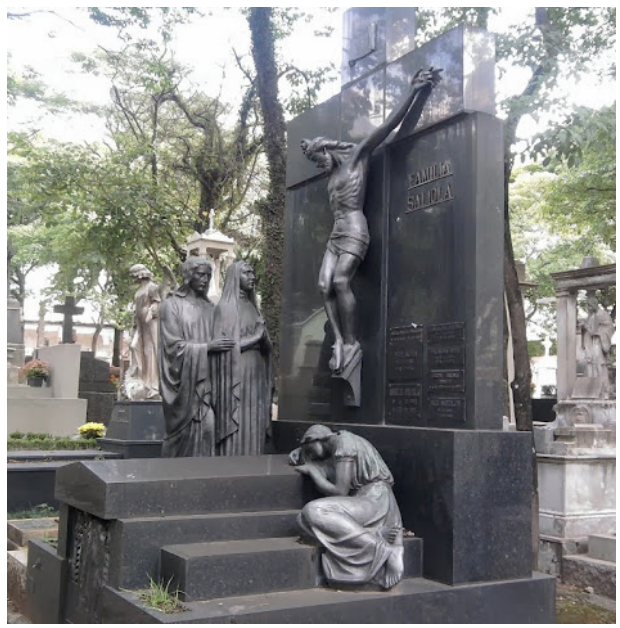

Cemitério da Consolação. ${ }^{53}$

52 Arquivo pessoal. Registro em 2010.

53 Arquivo pessoal. Registro em 2010. 


\section{Considerações finais}

Investigar a morte é uma forma de entender como, historicamente ou sincronicamente, os homens têm criado as relações de poder na sociedade e as cristalizado em suas culturas. O que quisemos apontar aqui foi, além disso, o fato de que a morte em ambientes tão distantes geográfica e culturalmente acaba sendo ritualizada de uma forma semelhante. Base para essa constatação é não apenas a relação contraditória que muitas sociedades têm com esse aspecto da vida, mas sobretudo a perspectiva de que a viagem portuguesa pelo mundo criou, de certa forma, essas aproximações que duram no tempo e no espaço.

Aproximar Macau e São Paulo, dois contextos tão diversos, termina por abrir espaço para fazer outras aproximações. Não no sentido do apagamento, mas no sentido da busca de diferentes formas de viver uma herança cultural, como a que praticamos aqui e acolá para ritualizar a morte e ritualizar a vida.

\section{Referências}

Andrade, Oswald de. Poesias reunidas. São Paulo: Círculo do livro, 1976. p. 197.

ARIÈs, Philippe. História da morte no Ocidente. Rio de Janeiro:

Ediouro, 2003.

Baudelaire, Charles. As flores do mal. Tradução de Ivan Junqueira. Rio de Janeiro: Nova Fronteira, 1985.

Braet, Herman; Verbeke, Werner (Ed.). A morte na Idade Média. Tradução de Heitor Megale, Yara Frateschi, Maria Clara Cescato. São Paulo: Edusp, 1996. 
Benedict, Ruth. Padrões de cultura. Lisboa: Livros do Brasil, s/d. Bertolli Filho, Gláudio; Meiny, José Carlos Sebe Bom. Morte e sociedade em Lima Barreto. In: Martins, José de Souza (Org.). A morte e os mortos na sociedade brasileira. São Paulo: Hucitec, 1983. p. 142-169.

Consorte, Josildeth. A morte na prática médica. In: MARTins, José de Souza (Org.). A morte e os mortos na sociedade brasileira. São Paulo: Hucitec, 1983. p. 38-57.

Enclyclopaedia Britannica: a new survey of Universal Knowledge. Vol. 8. Chicago, London, Toronto, Encyclopædia Britannica, Inc., 1768.

Fontes, Ofélia. O indio brasileirinho. Rio de Janeiro: Primor, 1976.

Holanda, Aurélio Buarque de. Novo Aurélio Século XXI: o dicionário da língua portuguesa. Rio de Janeiro: Nova Fronteira, 1999.

Javovitch, Paula. Além muros. Revista Cidade, n. 4, p. 126-129, 1996. Disponível em: https://versaopaulo.wordpress.com/2013/11/18/alem-muros/. Acesso em: 20 set. 2017.

Leoni, Francisco Evaristo. Genio da Lingua Portugueza, ou causas racionaes e philologicas de todas as formas e derivações da mesma lingua, commprovadas com innumeraveis exemplos extrahidos dos auctores latinos e vulgares. Tomo I. Lisboa: Typographia do Panorama, 1858.

Magalhães, Ana Paula Tavares de. Resenha de $A$ morte na idade média. Revista de História, São Paulo, n. 137, p. 145-149, 1997. Disponível em: www.revistas.usp.br/revhistoria/article/ view/64540 Acesso em: 20 set. 2017. 
Malraux, André. Romans: Les conquérants. La condition humaine. L'espoir. Gallimard, 1952. Disponível em: <http://www. frasesdepensadores.com.br/frase/morte-transforma-vida-em-destino/>. Acesso em: 20 set. 2017.

Marcílio, Maria Luiza. A morte de nossos ancestrais. In: Martins, José de Souza (org:). A morte e os mortos na sociedade brasileira. São Paulo: Hucitec, 1983. p. 61-75.

Marques, António Henrique Rodrigo de Oliveira. A sociedade medieval portuguesa: aspectos da vida cotidiana. Lisboa: Sá da Costa, 1971.

Marques, Manuel Eufrásio de Azevedo. Apontamentos históricos, geográficos, biográficos, estatísticos e noticiosos da Província de São Paulo seguidos da Cronologia dos acontecimentos mais notáveis desde a fundação da Capitania de São Vicente até o ano de 1876. Publicações comemorativas sob o alto patrocínio da Comissão do IV Centenário da Cidade de São Paulo. São Paulo: Biblioteca Histórica Paulista, s/d.

Martins, José de Souza. História e Arte no Cemitério da Consolação. Folder para visitação pública da Prefeitura da Cidade de São Paulo. s/d.

Matos, Alderi Souza de. O cemitério dos protestantes de São Paulo. Disponível em: <http://www.mackenzie.br/10221.html>. Acesso em: 23 fev. 2015.

Melo Neto, João Cabral de. Antologia poética. Rio de Janeiro: Editora do Autor, 1965.

Queiroz JR., Teófilo de. Dos mortos e sua volta. In: Martins, José de Souza (Org.). A morte e os mortos na sociedade brasileira. 
São Paulo: Hucitec, 1983. p. 103-112.

Rezende, Eduardo Coelho Morgado. O enigma dos cemitérios da cidade de São Paulo. In: Rezende, Eduardo Coelho Morgado; FErreira, Ricardo Vicente (org.). A Geografia fora da sala de aula. São Paulo: Necrópolis, 2008. p. 99-109.

Ribeiro, Marily Simões. Arqueologia das práticas mortuárias. São Paulo: Alameda, 2007.

Rodrigues, José Carlos. O corpo na história. Rio de Janeiro: Fiocruz, 1999.

Ruffié, Jacques. O sexo e a morte. Tradução de Carlota Gomes. Rio de Janeiro: Nova Fronteira, 1988.

Santos, Célia Almeida Ferreira. Os profissionais de saúde enfrentam-negam a morte. In: Martins, José de Souza (Org.). A morte e os mortos na sociedade brasileira. São Paulo: Hucitec, 1983. p. 15-24.

Silva, Da Costa e; Carvalho, Myrtis de; Toledo, Caio Alves de. Dicionário Universal de Curiosidades. São Paulo: CIL, 1968. Vomero, Maria Fernanda. Morte. Superinteressante, São Paulo, n. 173, p. 36-44, fev. 2002.

Lima-Hernandes, Maria Célia; Teixeira e Silva, Roberval. No descanso eterno entre lápides e epitáfios: São Miguel Arcanjo e Consolação. In: Simas, Monica (Org.). Estudos sobre Macau e outros orientes. São Paulo: Paulistana, 2017. p. 128-168. 